\title{
UPAYA PENINGKATAN KOMPETENSI BELAJAR BAHASA INDONESIA MELALUI METODE DISKUSI KELOMPOK MENGGUNAKAN POINT SYSTEM BAGI SISWA KELAS X SMAN 16 TEBO
}

\author{
PUWERMAN \\ SMA Negeri 16 Kabupaten Tebo Provinsi Jambi \\ Email : spuwermanpraja@yahoo.com
}

\begin{abstract}
ABSTRAK
Penelitian ini bertujuan untuk meningkatkan kompetensi belajar bahasa Indonesia melalui metode diskusi kelompok menggunakan point system bagi siswa kelas X di SMA Negeri 16 Kabupaten Tebo Provinsi Jambi tahun pelajaran 2016/2017. Jenis penelitian yang dilakukan adalah penelitian tindakan kelas (PTK). Subjek penelitian adalah siswa kelas X SMA Negeri 16 Kecamatan Rimbo Ulu Kabupaten Tebo Provinsi Jambi tahun pelajaran 2016/2017, yang berjumlah 30 siswa. Penelitian tindakan kelas ini menggunakan model yang dikembangkan oleh Kemmis dan Mc. Teggart, terdiri dari II siklus yang setiap siklusnya terdiri dari perencanaan (Plan), tindakan (action), pengamatan (observation), dan kontemplasi (reflection). Pelaksanaan setiap siklus terdiri dari 2 pertemuan dengan rincian dua pertemuan untuk melaksanakan proses pembelajaran satu sesi ( 2 x 45 menit) untuk ulangan harian. Hal ini dibuktikan pada pertemuan I persentase yang mengajukan pertanyaan hanya $10,2 \%$, yang mengeluarkan pendapat $5,25 \%$, mencatat sebanyak $15,78 \%$, dan yang mengikuti pembelajaran sebesar $14,42 \%$ dengan total jumlah persentase sejumlah 45,65\%. Kemudian selanjutnya meningkat pada Siklus II yakni persentase yang mengajukan pertanyaan hanya $21,05 \%$, yang mengeluarkan pendapat $23,86 \%$, mencatat sebanyak $34,21 \%$, dan yang mengikuti pembelajaran sebesar $18,45 \%$ dengan total jumlah persentase sejumlah $97,39 \%$. Maka setelah melihat hasil pertemuan I dan II peneliti menerapkan point system pada pertemuan selanjutnya, maka terdapat hasil yang signifikan, terdapat hasil pengamatan yang meningkat dari siklus I ke siklus II. Peningkatan terjadi di siklus II karena telah diterapkannya point system.
\end{abstract}

Kata Kunci: kompetensi belajar Bahasa Indonesia, diskusi kelompok, point system.

\section{PENDAHULUAN}

Pendidikan adalah kegiatan yang selalu harus sadar tujuan. Oleh karena itu perumusan tujuan pendidikan bukan saja penting, tetapi merupakan suatu keharusan. Tujuan pendidikan ada beberapa tingkat, yaitu: (a) tujuan pendidikan nasional, (b) tujuan institusional, (c) tujuan pendidikan kurikuler, dan (d) tujuan instruksional. Tujuan pendidikan nasional merupakan rumusan umum tentang pola perilaku dan pola kemampuan yang harus dimiliki oleh lulusan suatu lembaga atau institusi pendidikan. Tujuan institusional ditentukan oleh tugas dan fungsi yang dipikul oleh lembaga tadi dalam rangka menghasilkan lulusan dengan kemampuan dan keterampilan tertentu yang dibutuhkan masyarakat (Sujana, 2019).

Tujuan pendidikan kurikuler adalah rumusan umum tentang macam-macam pengetahuan, ketrampilan, dan kemampuan yang terdapat dalam masing masing mata pelajaran sehingga dapat diberikan pengalaman yang sesuai kepada siswa dalam rangka mencapai tujuan institusional lembaga pendidikan yang bersangkutan. Tujuan ini didasarkan pada tingkah laku, yaitu tujuan pendidikan yang berhubungan dengan terbentuknya tingkah laku. Ada tiga macam tingkah laku yang dikenal dengan istilah taksonomi. Bloom membagi tujuan ini menjadi tiga (taksonomi Bloom), yaitu ranah kognitif (cognitive domain), ranah afektif (affective domain), dan ranah psikomotorik (Psycomotoric domain) (Efendi, 2017).

Kemajuan suatu negara tergantung pada sistem pendidikan. Peningkatan mutu pendidikan merupakan sasaran pembangunan di bidang pendidikan nasional dan merupakan bagian integral dari upaya peningkatan kualitas manusia Indonesia secara menyeluruh. Pendidikan merupakan suatu upaya untuk meningkatkan kualitas sumber daya manusia baik secara intelektual, psikologi, maupun aspek sosial. Seseorang dapat dikatakan telah berhasil 
dalam belajar jika ia mampu menunjukkan adanya perubahan dalam kemampuan berfikir, keterampilan, dan sikap (Jannah, 2017). Kemampuan guru dalam proses pembelajaran sangat mempengaruhi perkembangan pendidikan. Hal ini karena tidak semua guru dapat mengajar muridnya dengan baik atau profesional. Pada kenyataannya dalam melaksanakan pengajaran, banyak pendidik yang masih mengalami kesulitan untuk memberikan pengajaran kepada murid sehingga murid sulit untuk memahami materi (Sakti, dkk, 2019). Keberhasilan pembelajaran di kelas sangat ditentukan oleh guru. Kegiatan guru di dalam kelas meliputi dua hal pokok, yaitu mengajar dan mengelola kelas. Kegiatan mengajar dimaksudkan secara langsung menggiatkan siswa mencapai tujuan-tujuan. Kegiatan mengelola kelas bermaksud menciptakan dan mempertahankan suasana (kondisi) kelas agar kegiatan mengajar itu dapat berlangsung secara efektif dan efisien (Minsih, 2018).

Peranan guru dalam menyampaikan materi pembelajaran kepada siswa tidaklah mudah. Guru harus memiliki berbagai kemampuan yang dapat menunjang tugasnya agar tujuan pendidikan dapat tercapai. Salah satu kemampuannya yang harus dimiliki oleh seorang guru dalam meningkatkan kompetensi profesinya adalah kemampuan memilih metode mengajar. Mengajar dalam konteks proses pembelajaran tidak hanya sekedar mempunyai materi pembelajaran, akan tetapi juga dimaknai sebagai proses mengatur lengkungan supaya peserta didik belajar. Walaupun istilah yang digunakan "pembelajaran". Tidak berarti guru harus menghilangkan perannya sebagai pengajar (Kirom, 2017). Dalam konteks pembelajaran, sama sekali tidak berarti memperbesar peranan peserta didik disatu pihak dan memperkecil peranan guru dipihak lain. Peran guru dan peserta didik yang dimaksud di sini adalah berkaitan dengan peran dalam proses pembelajaran. Guru dan peserta didik merupakan faktor penentu yang sangat dominan dalam pendidikan umumnya, karena guru dan peserta didik memegang peranan dalam proses pembelajaran, di mana proses pembelajaran merupakan inti dari proses pendidikan secara keseluruhan yang bertujuan terjadinya perubahan tingkah laku anak.

Memilih metode mengajar seorang guru harus dapat menyesuaikan antara metode yang dipilihnya dengan kondisi siswa, materi pelajaran dan sarana yang ada. Oleh karena itu guru harus menguasai beberapa jenis metode mengajar agar proses belajar mengajar berjalan lancar dan tujuan yang ingin dicapai dapat terwujud. Untuk meningkatkan kemampuan siswa dan meningkatkan motivasi dan hasil belajar siswa dalam mengikuti pelajaran, dan beberapa metode mengajar yang tepat digunakan.

Manusia adalah makhluk sosial, maka keberadaannya akan dapat dikembangkan dalam kebersamaan dengan sesamanya. Potensi yang dimiliki seseorang akan terasah jika dalam kesempatan tertentu ada interaksi dengan orang lain. Begitu pula siswa sebagai individu dalam mewujudkan dirinya sebagai manusia dilingkungannya harus terbiasa dengan kegiatankegiatan yang mencerminkan perilaku penuh tanggung jawab terhadap sesamanya. Sekolah adalah tempat untuk membantu siswa menemukan jati dirinya sebagai bagian dari masyarakat. Diskusi kelompok merupakan salah satu strategi belajar-mengajar yang sesuai. Menurut $\mathrm{O}$. Nyumba (2018), kelompok belajar yang dimaksud dalam strategi belajarmengajar ini adalah dynamic group (kelompok dinamik). Tidak semua kumpulan manusia termasuk dalam apa yang dimaksud dalam kelompok (dinamik). Kelompok dinamik yang dimaksud mempunyai lima ciri pokok yaitu: 1) Interaksi, 2) Tujuan, 3) Kepemimpinan, 4) Norma, 5) Emosi. Metode diskusi dapat pula diartikan sebagai siasat "penyampaian" bahan ajar yang melibatkan peserta didik untuk membicarakan dan menemukan alternatif pemecahan suatu topik bahasan yang bersifat problematis. Guru, peserta didik atau kelompok peserta didik memiliki perhatian yang sama terhadap topik yang dibicarakan dalam diskusi (Silalahi, 2017).

Metode diskusi kelompok adalah format pembelajaran yang menitikberatkan kepada interaksi antara anggota yang satu dengan anggota yang lain dalam satu kelompok guna menyelesaikan tugas-tugas belajar secara bersama-sama. Metode ini dapat digunakan jika guru mempunyai keyakinan bahwa untuk memahami topik yang dibicarakan perlu dilakukan pembelajaran dengan metode diskusi dan kerja kelompok. Kerja Kelompok dapat dikategorikan ke dalam pendekatan ekspositori apabila dimaksudkan untuk mengarahkan mahasiswa terhadap 
tujuan yang telah ditentukan sebelumnya (directed discussion). Biasanya siswa diuji dan dinilai kecakapannya dalam mengidentitikasi peristiwa, tanggal peristiwa, rumus-rumus, dan mengulangi informasi yang telah disampaikan oleh guru sesuai dengan aslinya atau sekurangkurangnya mengenai substansinya (Karall, 2019).

Menentukan strategi pembelajaran dalam diskusi kelompok guru dapat menggunakan pendekatan ekspositori atau pendekatan inkuiri. Pendekatan ekspositori merupakan suatu pendekatan di mana guru menyajikan informasi kepada siswa. Sumber-sumber informasi yang paling banyak digunakan adalah buku teks dan bahan-bahan rujukan lain yang relevan seperti bahan-bahan audio-visual dan pengalaman pribadi guru (Hidayat, dkk, 2012). Biasanya guru berdiri di depan kelas menyajikan informasi, sedangkan siswa diharapkan memproses informasi tersebut dengan cara yang sama seperti yang disajikan oleh guru. Berdasarkan pendapat tersebut dapat dikatakan bahwa strategi pembelajaran mencakup: (a) Perencanaan pengajaran yang meliputi materi pelajaran, metode mengajar, media pengajaran, lingkungan belajar, pengelolaan kelas, dan urutan-urutan peristiwa dalam proses pembelajaran. (b) Tujuan pengajaran diarahkan untuk mengubah pengetahuan menjadi belajar yang meliputi perubahan perilaku individu dalam ranah kognitif, ranah afektit, dan ranah psikomotor (Kurniawan, 2016).

Tujuan penggunaan metode diskusi dalam kegiatan belajar mengajar adalah: (a) Memupuk kemauan dan kemampuan kerja sama diantara para siswa. (b) Meningkatkan keterlibatan sosio-emosional dan intelektual dan para siswa dalam proses pembelajaran yang diselenggarakan. (c) Meningkatkan perhatian terhadapproses dan hasil dari proses pembelajaran secara berimbang. Variabel-variabel yang menentukan keberhasilan kerja kelompok antara lain: (a) Tujuan yang jelas. (b) Interaksi anggota kelompok. (c) Kepemimpinan kelompok. (d) Suasana kerja kelompok. (e) Tingkat kesulitan tugas. Selanjutnya, (f) Kemampuan dan kecakapan guru dalam menjalankan perannya sebagai pengelola, pengamat, pemberi saran, dan penilai. Prosedur penggunaan metode ini dalam kegiatan belajar mengajar adalah (a) Tahap persiapan, (b) Pemilihan topik (Mazfufah, 2017).

Pendekatan inkuiri merupakan suatu pendekatan dalam strategi pembelajaran, dalam pendekatan ini guru bertindak sebagai fasilitator pengalaman belajar serta menciptakan dan mengatur kondisi-kondisi yang dapat memberikan rangsangan kepada para siswa untuk mengajukan pertanyaan-pertanyaan tentang topik yang sedang dibahas. Misalnya guru menyajikan dokumen-dokumen transaksi keuangan yang diperoleh dari suatu perusahaan jasa hipotetis dan kemudian mendorong para siswa untuk mengajukan pertanyaan-pertanyaan yang hanya dijawab oleh guru dengan menyatakan "ya" atau "tidak". Dari pertanyaan siswa dan jawaban yang diberikan oleh guru tersebut diharapkan tercipta suatu kondisi terjadinya inkuiri.

Salah satu model perencanaan pembelajaran yang harus dipersiapkan guru adalah Rencana Pelaksnaan Pembelajaran (RPP). RPP pada hakikatnya adalah proyeksi tentang apa yang harus dilakukan guru pada waktu melaksanakan kegiatan pembelajaran, tidak lain adalah perbuatan atau tingkah laku mengajar. Perbuatan mengajar dalam hal ini guru melaksanakan menentukan metode yang akan digunakan dalam proses pembelajaran, sehingga dapat mempengaruhi siswa secara efektif dan efisien untuk mencapai tujuan pembelajaran yang telah direncanakan. RPP merupakan pegangan bagi guru dalam melaksanakan pembelajaran baik di kelas atau lapangan untuk setiap Kompetensi Dasar. Oleh karena itu, apa yang tertuang di dalam RPP memuat hal-hal yang langsung berkait dengan aktivitas pembelajaran dalam upaya pencapaian penguasaan suatu Kompetensi Dasar (Wardani, 2012).

Hipotesis yang diajukan dalam penelitian ini adalah terdapat pengaruh penggunaan metode diskusi kelompok dalam pembelajaran bahasa Indonesia terhadap peningkatan kompetensi siswa dalam pembelajaran bahasa Indonesia dengan tipe kerja kelompok maka kompetensi dalam pembelajaran bahasa Indonesia siswa kelas X SMA N 16 Kabupaten Tebo Provinsi Jambi tahun pelajaran 2016/2017 Meningkat. 
Jenis penelitian yang dilaksanakan adalah Penelitian Tindakan Kelas (PTK). Menurut Arikunto (2005: 4) yaitu melakukan tindakan yang sesuai dengan permasalahan yang ada dil apangan yang harus diperbaharui dan ditingkatkan praktik-praktik pembelajaran secara proposional. Penelitian tindakan kelas (PTK) yang dilakukan peneliti di kelas X SMA Negeri 16 Kabupaten Tebo pada sekolah tempat peneliti melakukan kegiatan mengajar dengan penekanan pada peningkatan kompetensi siswa dalam penguasaan materi pembelajaran bahasa indonesia.

Subjek penelitian adalah siswa kelas X SMA Negeri 16 Kabupaten Tebo semester I tahun ajaran 2016/2017 yang berjumlah 30 siswa. Penelitian tindakan kelas ini menggunakan model yang dikembangkan oleh Kemmis dan Mc. Teggart, terdiri dari dua siklus tiap siklus terdiri atas perencanaan (Plan), tindakan (action), pengamatan (observation), dan perenungan (reflection). Pelaksanaan tiap siklus terdiri dari 2 kali pertemuan dengan perincian 2 kali pertemuan untuk melaksanakan proses pembelajaran dari satu kali pertemuan ( 2 x 45 menit) untuk ulangan harian. Selanjutnya diuraikan dengan langkah-langkah kegiatan yang dilaksanakan selama tiga kali pertemuan di setiap siklus yang meliputi perencanaan, pelaksanaan, observasi, dan refleksi. Untuk mengetahui aktivitas siswa selama proses pembelajaran berlangsung, penulis menggunakan lembaran observasi yang telah disediakan pada penelitian ini yaitu lembaran observasi yang di isi oleh peneliti dan lembaran observasi yang diisi oleh observer. Lembaran observasi yang diisi oleh observer adalah aktivitas setiap siswa setiap kali pertemuan. Sedangkan lembaran observasi yang telah diisi oleh peneliti adalah lembaran angket dan tes hasil belajar melalui ulangan harian yang dilaksanakan setelah satu kali pertemuan atau satu siklus.

Analisis data hasil observasi keaktifan siswa selama proses pembelajaran berlangsung. Dihitung dalam proses persentase dengan rumus:

$\frac{\text { Jumlah siswa aktif }}{\text { Jumlah siswa keseluruhan }}$

Kemudian persentase aktifitas di terjemahkan kedalam kriteria menurut Arikunto (2005:241).

$$
\begin{array}{ll}
81-100 \% & =\text { Sangat tinggi } \\
61-80 \% & =\text { Tinggi } \\
41-60 \% & =\text { Cukup } \\
21-40 \% & =\text { Rendah } \\
0-20 \% & =\text { Sangat rendah }
\end{array}
$$

\section{HASIL DAN PEMBAHASAN}

Penelitian tindakan kelas yang dilakukan sesuai dengan rangkaian kegiatan mulai dari perencanaan, tindakan, observasi dan refleksi yang dilakukan setiap siklus. Berdasarkan pengalaman penulis terhadap siswa kelas X, selama pengalaman lapangan, kompetensi belajar bahasa Indonesia sangat rendah hal ini terlihat dari: (a) Aktivitas belajar siswa, bertanya, menjawab dan mengeluarkan pendapat sangat rendah. (b) Banyak yang tidak siap untuk belajar, seperti bermain-main dan bercerita dengan teman. (c) Banyaknya yang tidak membuat latihan atau tugas dengan berbagai alasan.

Penelitian ini dilakukan sebanyak tiga kali pertemuan, kompetensi dasar pada pembelajaran pada pertemuan ini adalah Menganalisis struktur, isi (permasalahan, argmentasi, pengetahuan, dan rekomendasi), kebahasaan teks eksposisi yang didengar dan atau dibaca. Di dalam proses pembelajaran dilaksanakan dalam membahas pokok pembahasan tersebut digunakan metode diskusi kelompok dan poin sistem. Dimana di dalam pembahasan ini siswa dibagi menjadi 6 kelompok masing-masing kelompok terdiri dari 6 orang. Tiap kelompok diberikan pokok bahasan yang berbeda. Sebelum proses pembelajaran berlangsung siswa diberitahukan akan adanya point system, hal tersebut bertujuan untuk memacu siswa supaya aktif dalam pembelajaran, dan di tambah dengan sedikit pengalaman yang dialami peneliti. 
Siswa diberikan waktu 25 menit untuk diskusi kelompok, setelah itu siswa dituntut untuk mempresentasekan hasil kelompoknya. Siswa juga diberikan kesempatan untuk aktif bertanya selama proses pembelajaran berlangsung.

Adapun Tiap-tiap pertemuan di dalam proses pembelajaran digunakan metode diskusi kelompok. (a) Apresiasi dan motivasi selama 10 menit (b) Eksplorasi selama 15 menit (c) Diskusi kelompok selama 25 menit (d) Presentase hasil diskusi selama 30 menit (e) membuat kesimpulan 10 menit. Dengan adanya pembagian waktu sebaik-baiknya metode ini bisa dikatakan bisa meningkatkan aktivitas, minat dan motivasi dan siswa mampu menguasai materi terhadap pembelajaran. Dengan metode ini $70 \%$ siswa aktif dalam mengajukan pertanyaan serta mengeluarkan pendapat di dalam melaksanakan diskusi. Siswa tidak lagi malu mengeluarkan pendapatnya, karna dengan adanya keaktifan siswa akan mendapatkan poin yang banyak bagi tiap-tiap siswa yang ikut berpartisipasi.

Di dalam pertemuan I dan II dapat dilihat kompetensi belajar siswa yang masih menggunakan metode ceramah dan mencatat bisa dilihat pada siklus I pada tabel berikut:

Tabel 1. Siklus I

\begin{tabular}{lllcccc}
\hline & & \multicolumn{4}{c}{ Pertemuan } \\
No & \multicolumn{1}{c}{ Aktivitas } & \multicolumn{3}{c}{ I } & \multicolumn{2}{c}{ II } \\
& & Jumlah & Persen & Jumlah & Persen \\
1 & Mengajukan pertanyaan & 4 & $16,21 \%$ & 4 & $10,2 \%$ \\
2 & Mengeluarkan pendapat & 1 & $2,63 \%$ & 2 & $5,25 \%$ \\
3 & Mencatat keterangan & 5 & $13,15 \%$ & 6 & $15,78 \%$ \\
4 & Semangat mengikuti pembelajaran & 5 & $13,15 \%$ & 7 & $14,42 \%$ \\
& & & & & $\mathbf{4 5 , 6 5 \%}$ \\
\hline
\end{tabular}

Dari data di atas dapat dilihat bahwa keaktifan siswa dalam pembelajaran masih kurang. Peneliti mencoba melaksakan metode diskusi kelompok dangan point system, dimana sebelum melaksanakan proses pembelajaran siswa di beritahu adanya point system. Penulis juga meminta bantuan pamong untuk mengawasi dalam proses pembelajaran berikutnya. Hasil yang didapatkan dapat dilihat pada siklus II pada tabel berikut:

Tabel 2. Siklus II

\begin{tabular}{lllcccc}
\hline & & \multicolumn{4}{c}{ Pertemuan } \\
No & \multicolumn{1}{c}{ Aktivitas } & \multicolumn{2}{c}{ I } & \multicolumn{2}{c}{ II } \\
& & Jumlah & Persen & Jumlah & Persen \\
1 & Mengajukan pertanyaan & 8 & $21,05 \%$ & 8 & $21,05 \%$ \\
2 & Mengeluarkan pendapat & 7 & $18,42 \%$ & 9 & $23,68 \%$ \\
3 & Mencatat keterangan & 10 & $26,31 \%$ & 13 & $34,21 \%$ \\
4 & Semangat mengikuti pembelajaran & 12 & $14,45 \%$ & 12 & $18,45 \%$ \\
\hline
\end{tabular}

Dari tabel di atas dapat dilihat dengan menggunakan metode diskusi kelompok dan point system ini dapat meningkat minat dan semangat dalam belajar siswa, dan siswapun bisa memahami materi dengan baik sehingga mampu meningkatkan kompetensi para siswa itu sendiri. Dengan menggunakan metode ini bisa dikatakan $75 \%$ hasil belajar meningkat yang menunjukkan bahwa komepetensi siswa dapat dikatakan meningkat. 


\section{Pembahasan}

Penelitian yang dilakukan peneliti dengan dua siklus, dapat dilihat bahwa pendekatan ekspositori dan inkuiri dengan menggunakan metode diskusi kelompok dapat meningkatkan kompetensi belajar siswa dalam pembelajaran bahasa Indonesia seperti minat bertanya siklus I naik pada siklus ke II. Hal ini dibuktikan dengan peningkatan yang terlihat pada pertemuan I persentase yang mengajukan pertanyaan hanya $10,2 \%$, yang mengeluarkan pendapat $5,25 \%$, mencatat sebanyak $15,78 \%$, dan yang mengikuti pembelajaran sebesar $14,42 \%$ dengan total jumlah persentase sejumlah $45,65 \%$. Kemudian setelah itu di uji lagi pada pertemuan II hasil yang diperoleh dapat meningkat dari yang sebelumnya yakni persentase yang mengajukan pertanyaan hanya $21,05 \%$, yang mengeluarkan pendapat $23,86 \%$, mencatat sebanyak $34,21 \%$, dan yang mengikuti pembelajaran sebesar $18,45 \%$ dengan total jumlah persentase sejumlah 97,39\%. Setelah melihat hasil pertemuan I dan II peneliti menerapkan point system pada pertemuan selanjutnya, maka terdapat hasil yang signifikan, terdapat hasil pengamatan yang meningkat dari siklus I ke siklus II. Peningkatan terjadi di siklus II karena telah diterapkannya point system.

\section{KESIMPULAN}

Berdasarkan hasil penelitian yang dilakukan dengan judul "Upaya Peningkatan Kompetensi Belajar Bahasa Indonesia Melalui Metode Diskusi Kelompok Menggunakan Point System Bagi Siswa Kelas X SMAN 16 Kabupaten Tebo" ini, dapat disimpulkan bahwa penelitian ini terbukti dapat meningkatkan kompetensi belajar bahasa indonesia melalui metode diskusi kelompok menggunakan point system bagi siswa kelas X di SMA Negeri 16 Kabupaten Tebo Provinsi Jambi tahun pelajaran 2016/2017. Hal ini dibuktikan pada pertemuan I persentase yang mengajukan pertanyaan hanya $10,2 \%$, yang mengeluarkan pendapat $5,25 \%$, mencatat sebanyak $15,78 \%$, dan yang mengikuti pembelajaran sebesar $14,42 \%$ dengan total jumlah persentase sejumlah $45,65 \%$. Kemudian selanjutnya meningkat pada Siklus II yakni persentase yang mengajukan pertanyaan hanya $21,05 \%$, yang mengeluarkan pendapat $23,86 \%$, mencatat sebanyak $34,21 \%$, dan yang mengikuti pembelajaran sebesar $18,45 \%$ dengan total jumlah persentase sejumlah 97,39\%. Maka setelah melihat hasil pertemuan I dan II peneliti menerapkan point system pada pertemuan selanjutnya, maka terdapat hasil yang signifikan, terdapat hasil pengamatan yang meningkat dari siklus I ke siklus II. Peningkatan terjadi di siklus II karena telah diterapkannya point system.

\section{DAFTAR PUSTAKA}

Arikunto, Suharsimi. (2005). Manajemen Penelitian. Yogyakarta: Rineka

Effendi, R. (2017). Konsep revisi taksonomi Bloom dan implementasinya pada pelajaran matematika SMP. JIPMat, 2(1).

Hidayat, S., Festiyed, F., \& Fauzi, A. (2012). Pengaruh Pemberian Assessment Essay Terhadap Pencapaian Kompetensi Siswa Dalam Pembelajaran Fisika Menggunakan Pendekatan Ekspositori dan Inkuiri di Kelas XI IA SMA N 1 Kecamatan Suliki Kabupaten Lima Puluh Kota. Jurnal Penelitian Pembelajaran Fisika, 1(1).

Jannah, R. (2017). Upaya meningkatkan keberhasilan pembelajaran pendidikan agama Islam. Madrosatuna: Journal of Islamic Elementary School, 1(1), 47-58.

Karall, W. R. (2019). THE INFLUENCE OF SMALL GROUP DISCUSSION METHOD ON STUDENTS'READING COMPREHENSION ON SMK PGRI 2 KEDIRI.

Kirom, A. (2017). Peran guru dan peserta didik dalam proses pembelajaran berbasis multikultural. Jurnal Al-Murabbi, 3(1), 69-80.

Kurniawan, K. (2016). Strategi Pembelajaran Bahasa Indonesia Berdasarkan Pendekatan Komunikatif. Jurnal Ilmu Pendidikan, 9(4).

Mazfufah, N. F. (2017). Pengaruh metode diskusi isu-isu sosiosaintifik terhadap kemampuan penalaran ilmiah peserta didik (Bachelor's thesis, fitk).

Minsih, M. (2018). Peran guru dalam pengelolaan kelas. Profesi pendidikan dasar, 5(1), 20-27. 
O. Nyumba, T., Wilson, K., Derrick, C. J., \& Mukherjee, N. (2018). The use of focus group discussion methodology: Insights from two decades of application in conservation. Methods in Ecology and evolution, 9(1), 20-32.

Sakti, T. K., Hairunisya, N., \& Sujai, I. S. (2019). Pengaruh Kompetensi Pedagogik Guru dan Gaya Belajar Siswa Terhadap Prestasi Belajar Siswa Pada Mata Pelajaran IPS. Jurnal Pendidikan Ilmu Sosial, 28(1), 53-60.

Silalahi, D. E. (2017). The Effect Of Small Group Discussion Technique On Students Reading Comprehension Ability.

Sujana, I. Wayan Cong. "Fungsi dan tujuan pendidikan Indonesia." Adi Widya: Jurnal Pendidikan Dasar 4.1 (2019): 29-39.

Wardani, O. P. (2012). Pengembangan perangkat evaluasi berdasarkan taksonomi The Structure Of Observed Learning Outcome (SOLO) pada mata pelajaran bahasa indonesia kompetensi membaca peserta didik kelas X SMA. Seloka: Jurnal Pendidikan Bahasa dan Sastra Indonesia, 1(2). 